\title{
The expression of genes involved in hepatic metabolism is altered by temporary changes to milking frequency
}

\author{
T. M. Grala, ${ }^{\dagger} \dagger^{1}$ J. R. Roche, ${ }^{*}$ J. K. Kay, ${ }^{*}$ A. G. Rius, ${ }^{\star}$ H. M. White, $\neq$ S. S. Donkin, $\S$ M. D. Littlejohn, ${ }^{* 2}$ \\ R. G. Snell, $†$ and C. V. C. Phyn* \\ *DairyNZ, Newstead, Hamilton 3286, New Zealand \\ †University of Auckland, Auckland 1010, New Zealand \\ ‡Department of Dairy Science, University of Wisconsin-Madison, Madison 53706 \\ §Department of Animal Sciences, Purdue University, West Lafayette 47907, IN
}

\begin{abstract}
Changes to milking frequency (MF) affect the metabolic and energetic status of dairy cows. However, the duration of altered MF necessary to modify hepatic transcription during early lactation is less clear. Additionally, long-term responses to short-term alterations in MF have not been established. Holstein-Friesian dairy cows $(\mathrm{n}=120)$ were allocated to 3 or 6 wk of either once-daily $(1 \times)$ or thrice-daily $(3 \times)$ milking, immediately postpartum. Following treatment, cows were switched to twice-daily $(2 \times)$ milking. These 4 treatment groups were compared with cows milked $2 \times(\mathrm{n}=$ 30) for the whole lactation. Liver tissue was collected by biopsy at $1,3,6$, and 9 wk postpartum from 12 cows per treatment, RNA was extracted, and transcript abundance of genes involved in hepatic metabolism was quantified. Milking frequency altered the expression of most of the genes measured; however, we observed no effects caused by the length of time on the alternative milking frequency and no interactions between MF and length. During the MF treatment, mRNA expression of some, but not all, genes involved in gluconeogenesis $(G 6 P C, P C K 1)$, fatty acid $\beta$-oxidation (CPT1A, CPT2), ketogenesis (HMGCS2), lipid transport (APOA1), and lipolysis (PNPLA2) were lower for cows milked $1 \times$ and plasma glucose and insulin concentrations were greater. Cows milked $3 \times$ had reduced mRNA expression for some of the genes involved in fatty acid synthesis $(A C A C A)$ and lipid transport $(A P O B)$ and had greater plasma NEFA concentrations at wk 1. At 9 wk postpartum, expression data indicated that cows previously milked $3 \times$ had a greater capacity for gluconeogenesis (PCK1), ketogenesis (HMGCS2), and urea cycling ( $A S L, C P S 1)$ and lower glucose concentrations than cows previously milked $1 \times$, because some of
\end{abstract}

Received July 30, 2013.

Accepted October 28, 2013.

${ }^{1}$ Corresponding author: talia.grala@dairynz.co.nz

${ }^{2}$ Current address: LIC, Newstead, Hamilton, New Zealand. the genes involved in these processes were still altered. Milking cows $1 \times$ relative to $2 \times$, however, did not result in significant carryover effects on the expression of the genes measured in this study, indicating that metabolic changes are not sustained beyond the period of reduced MF. Changes to MF altered the hepatic response during early lactation; however, this was not dependent on the duration of MF change. Although we observed only minimal carryover effects on hepatic metabolism from short periods of reduced MF postpartum, there may be long-term effects on urea cycling $(A S L, C P S 1)$ and ketogenesis (HMGCS2) when $3 \times$ milking occurs immediately postpartum.

Key words: energy balance, gene expression, early lactation, dairy cow

\section{INTRODUCTION}

In high-producing dairy cows, the energy output in milk production is greater than the energy intake during early lactation (Bauman and Elliot, 1983; Bell, 1995). This energy shortfall is met by mobilizing body tissue reserves (Grummer, 1995). As milking frequency (MF) alters milk production, changes to postpartum MF may affect the severity and duration of the negative energy balance (NEB) that occurs during this period (Rémond et al., 2002; Loiselle et al., 2009; Soberon et al., 2010). Bar-Peled et al. (1995) reported that plasma glucose concentrations were lower, whereas plasma NEFA concentrations were greater in cows milked 6 times daily compared with those milked 3 times daily $(3 \times)$ postpartum, indicating that increasing MF results in a greater metabolic and energy imbalance. This premise is supported by a study in which cows were milked $3 \times$ instead of twice daily $(2 \times)$ for 8 wk at the start of lactation (Andersen et al., 2004b). Furthermore, during the first $3 \mathrm{wk}$ postpartum, grazing cows milked $3 \times$ compared with $2 \times$ had greater BCS loss (Phyn et al. 2011), indicating greater body tissue mobilization to support milk production. 
Conversely, decreasing postpartum MF to once daily $(1 \times)$ does not require as much mobilization of body tissue reserves because milk production and energy demand are reduced compared with cows milked $2 \times$ (Rémond et al., 1999). Indeed, cows milked $1 \times$ have lower plasma NEFA concentrations and lesser BCS loss during early lactation (Patton et al., 2006; McNamara et al., 2008; Phyn et al., 2011). Additionally, plasma glucose and leptin concentrations are greater in cows milked 1× (Loiselle et al., 2009; Kay et al., 2013), indicating that less glucose is required to meet lower milk production demands and adipose tissue stores are greater compared with cows milked $2 \times$. The positive effects of a lower MF on energy balance during early lactation are consistent across experiments; however, the long-term effects of temporary changes to MF on metabolic status, as well as the effect of the duration of the altered postpartum MF, are less clear.

Increased mobilization of adipose tissue, due to the increased energy demand from more frequent milking, increases plasma NEFA concentrations (Loiselle et al., 2009; Soberon et al., 2010), which can be absorbed by the liver. Hepatic NEFA are oxidized through $\beta$-oxidation or can be re-esterified to synthesize triacylglycerides, which are then exported. Therefore, it is plausible that the previously reported changes in plasma NEFA concentrations with altered postpartum MF are also associated with concomitant changes in the expression of genes involved in hepatic FA synthesis, $\beta$-oxidation, ketogenesis, ureagenesis, and re-esterification (Loor et al., 2007). Additionally, the greater mammary demand for glucose with increased MF would be expected to alter the expression of genes involved in gluconeogenesis.

We hypothesized that changes to MF and subsequent changes to milk production during early lactation would alter the metabolic status of multiparous dairy cows, both during and after the MF challenge. To test this hypothesis, cows were randomly allocated to $1 \times$, $2 \times$, or $3 \times$ milking for either 3 or 6 wk postpartum. Expression of key rate-limiting genes was measured in the liver both during the MF change and after all cows were switched to $2 \times$ milking.

\section{MATERIALS AND METHODS}

\section{Experimental Design and Treatments}

The study was conducted at Lye Farm, DairyNZ (Hamilton; $37^{\circ} 46^{\prime} \mathrm{S} 175^{\circ} 18^{\prime} \mathrm{E}$ ) from July to November 2009. All treatments and measurements were approved by the Ruakura Animal Ethics Committee (Hamilton, New Zealand).

The experimental design, grazing management, and supplementary feeding of cows, milk production, BW, and BCS are as previously reported (Phyn et al., 2011). Briefly, multiparous Holstein-Friesian and HolsteinFriesian $\times$ Jersey dairy cows $(\mathrm{n}=150)$ were randomly allocated to 1 of 5 treatments ( $\mathrm{n}=30$ /treatment) immediately postpartum (mean \pm SD; July 15, $2009 \pm$ $10.6 \mathrm{~d})$. Treatments were (1) cows milked $2 \times$ for the entire lactation (control); (2) cows milked $1 \times$ for $3 \mathrm{wk}$ postpartum and $2 \times$ thereafter; (3) cows milked $1 \times$ for 6 wk postpartum and $2 \times$ thereafter; (4) cows milked $3 \times$ for 3 wk postpartum and $2 \times$ thereafter; or (5) cows milked $3 \times$ for 6 wk postpartum and $2 \times$ thereafter. Daily milking times were $0700 \mathrm{~h}$ for $1 \times(24$-h interval), 0700 and $1500 \mathrm{~h}$ for $2 \times(16-$ and 8 -h intervals), and 0700,1500 , and $2200 \mathrm{~h}$ for $3 \times(9-, 8-$, and 7 -h intervals).

All cows grazed a generous allowance of perennial ryegrass-clover pasture (30 to $40 \mathrm{~kg}$ of $\mathrm{DM} / \mathrm{cow}$ per day to target postgrazing residuals of $1,800 \mathrm{~kg}$ of DM/ ha) in the same paddock with $1 \times, 2 \times$, and $3 \times$ milking treatments separated by a double-stranded electric wire fence. Cows in the $1 \times$ and $3 \times$ treatments were moved into the $2 \times$ group after completing their MF challenge, and all cows grazed together for the remainder of the experiment. Before calving, cows were offered $2 \mathrm{~kg}$ (DM) per day of a pelleted maize-barley concentrate in the paddock starting 2 wk before their predicted calving date. Following calving, cows were individually offered $4 \mathrm{~kg}$ of DM concentrate per day during morning milking until November 1, 2009, and then $2 \mathrm{~kg}$ of DM per day until November 24, 2009. Pasture silage (averaging $3.6 \mathrm{~kg}$ of $\mathrm{DM} /$ cow per day) was offered for $40 \mathrm{~d}$ during July and August 2009, when pasture availability was limited.

\section{Milk and Blood Sampling and Measurements}

Milk production and BCS measurements were as described elsewhere (Phyn et al., 2011). Briefly, individual milk yields and milk composition (fat, protein, and lactose) were determined daily and weekly, respectively. Body weight and BCS (1-10 scale, where $1=$ emaciated and $10=$ obese; Roche et al., 2004) were measured once a week until September and once every 2 wk thereafter. Blood was sampled on the same day each week for the first 12 wk postpartum. A 10-mL evacuated blood tube (Becton Dickinson, Franklin Lakes, NJ) containing 140 IU of sodium heparin was collected from each cow by coccygeal venipuncture immediately before the morning milking (approximately $0700 \mathrm{~h}$ ). Samples were placed on ice and then centrifuged at 1,120 $\times g$ for $12 \mathrm{~min}$ at $4^{\circ} \mathrm{C}$. Plasma was harvested and stored at $-20^{\circ} \mathrm{C}$ while awaiting subsequent analyses for metabolites (NEFA, glucose), and insulin.

Analyses for plasma concentrations of NEFA [acyl Co-A synthetase, acyl-CoA oxidase (ACS-ACOD) 
colorimetric method using the NEFA C kit from Wako, Osaka, Japan] and glucose [glucose oxidase/4aminophenazone/phenol (GOD-PAP) method determined photometrically] were performed on a Modular P800 analyzer (Roche, Basel, Switzerland) at $37^{\circ} \mathrm{C}$ by Gribbles Veterinary Pathology Ltd. (Hamilton, New Zealand). The inter- and intraassay $\mathrm{CV}$ were $<2 \%$ for all assays.

Plasma insulin (Hales and Randle, 1963; validated in bovine by Chagas et al., 2007) was measured in duplicate by double-antibody RIA by the University of Western Australia (Perth, Australia) with inter- and intraassay $\mathrm{CV}<6 \%$. The assay used insulin antiserum (GP2, 21/7/80) donated by Peter Wynn (Commonwealth Scientific and Industrial Research Organisation, Division of Animal Production, Blacktown, NSW, Australia) raised in guinea pigs by using bovine insulin (BI 4499, Ely Lilly Pty. Ltd., West Ryde, Sydney, Australia).

\section{Liver Tissue Sampling}

Liver tissue was collected at wk $1,3(20.5 \mathrm{~d} \pm 0.9)$, $6(41.8 \mathrm{~d} \pm 1.1)$, and $9(62.3 \mathrm{~d} \pm 1.0)$ postpartum from a randomly selected subset of cows $(n=12$ /treatment) ensuring that treatments were balanced to limit variation. The wk 1 sample was only collected from cows in $2 \times, 1 \times$ for $3 \mathrm{wk}$, and $3 \times$ for $3 \mathrm{wk}$ treatment groups to minimize the number of cows subjected to 4 consecutive biopsies. This encompassed all the treatments at this time point, as duration was not a factor until the wk 6 biopsy. Subsequent liver samples were collected from all treatments $(\mathrm{n}=12 /$ treatment). Controlled intravaginal drug releasing devices (Zoetis, NSW, Australia) containing $1.38 \mathrm{~g}$ of progesterone were inserted 2 $\mathrm{d}$ before and removed at the time of biopsies to prevent estrus behaviors around the time of sampling.

Liver sample collection was performed from an area in the 11th intercostal space, as described by Lucy et al. (1998), resulting in samples of approximately 200 mg. Biopsies were immediately placed in screw-capped micro-centrifuge tubes and snap-frozen in liquid nitrogen. Samples were stored at $-80^{\circ} \mathrm{C}$ until RNA extraction (6 mo later).

\section{Extraction of RNA and cDNA Synthesis}

Total cellular RNA was isolated from the liver samples ( $\sim 30 \mathrm{mg}$ ) using a TissueLyser II and a RNeasy kit (Qiagen, Hilden, Germany) according to the manufacturer's instructions. Total RNA was then treated with DNase (Ambion DNA-free kit; Ambion, Austin, TX). The quantity and purity of RNA were determined by spectrophotometry using a NanoDrop ND-1000 (Nano-
Drop Technologies, Wilmington, DE). The absorbance ratio at 260:280 $\mathrm{nm}$ of these samples was $>1.7$ (where $2=$ pure). The integrity of RNA was confirmed using the Agilent 2100 Bioanalyzer with a RNA 6000 Nano LabChip kit (Agilent Technologies, Palo Alto, CA). The RNA samples were stored at $-80^{\circ} \mathrm{C}$.

Of the 200 successful liver biopsies, RNA was extracted from 194. Final numbers for each treatment were 80 from $1 \times(3 \mathrm{wk}, \mathrm{n}=45 ; 6 \mathrm{wk}, \mathrm{n}=35), 44$ from $2 \times$, and 70 from $3 \times(3 \mathrm{wk}, \mathrm{n}=37 ; 6 \mathrm{wk}, \mathrm{n}=33)$, and these were even across all biopsy time points. Two micrograms of each liver RNA sample (final volume $=40$ $\mu \mathrm{L}$ ) was used for cDNA synthesis using the Invitrogen Superscript III Supermix kit (Invitrogen Corp., Carlsbad, CA). Total RNA was reverse transcribed using a final concentration of $27 \mu M$ of random pentadecamer primers according to the manufacturer's instructions. Reverse transcriptase negative controls were generated by excluding the enzyme. The cDNA samples were stored at $-20^{\circ} \mathrm{C}$.

\section{Quantitative PCR and mRNA Analyses}

Using reverse transcription quantitative PCR (RTqPCR) analysis, hepatic expression of 19 target genes was measured (Table 1). Assays were designed to publicly available bovine gene sequences (National Center for Biotechnology Information; http://www.ncbi.nlm. nih.gov/gene) using Roche Universal Probe Library design software. Assays were designed to span an intron-exon boundary of genes to prevent amplification of genomic DNA and the specificity of assays tested using BLAST (http://blast.ncbi.nlm.nih.gov/Blast.cgi; Altschul et al., 1990). The primer and probe sequences and location of the assays are presented in Table 1. Primers were manufactured by Invitrogen at $50 \mathrm{nmol}$ concentration and purified by desalting. The RT-qPCR was performed using Roche master mix (LightCycler 480 Probes Master) and Roche Universal Probe Library assays analyzed on the Roche LightCycler 480 (Roche Diagnostics, Mannheim, Germany). The RT-qPCR reaction volume was $10 \mu \mathrm{L}$, consisting of $4 \mu \mathrm{L}$ of cDNA and $6 \mu \mathrm{L}$ of master mix $(5 \mu \mathrm{L}$ of Roche Probes Master; $0.4 \mu \mathrm{L}$ of each $5 \mu M$ primer; $0.075 \mu \mathrm{L}$ of probe and 0.125 $\mu \mathrm{L}$ of $\left.\mathrm{H}_{2} \mathrm{O}\right)$. Reactions were set-up using an epMotion 5075 robot (Eppendorf, NSW, Australia) before plates were transferred into the LightCycler 480. Standard cycling conditions were used: $95^{\circ} \mathrm{C}$ for $10 \mathrm{~min},\left(95^{\circ} \mathrm{C}\right.$ for $10 \mathrm{~s}, 60^{\circ} \mathrm{C}$ for $\left.30 \mathrm{~s}\right) \times 45$ cycles, and $40^{\circ} \mathrm{C}$ for $40 \mathrm{~s}$.

To quantify gene expression, cDNA was diluted as per Table 1. Each RT-qPCR run included 2 negative controls (no cDNA and no reverse transcriptase) and 3 inter-run calibrators. Inter-run calibrators were necessary as the number of samples required 2 plates to 
Table 1. Characteristics of gene-specific quantitative PCR assays

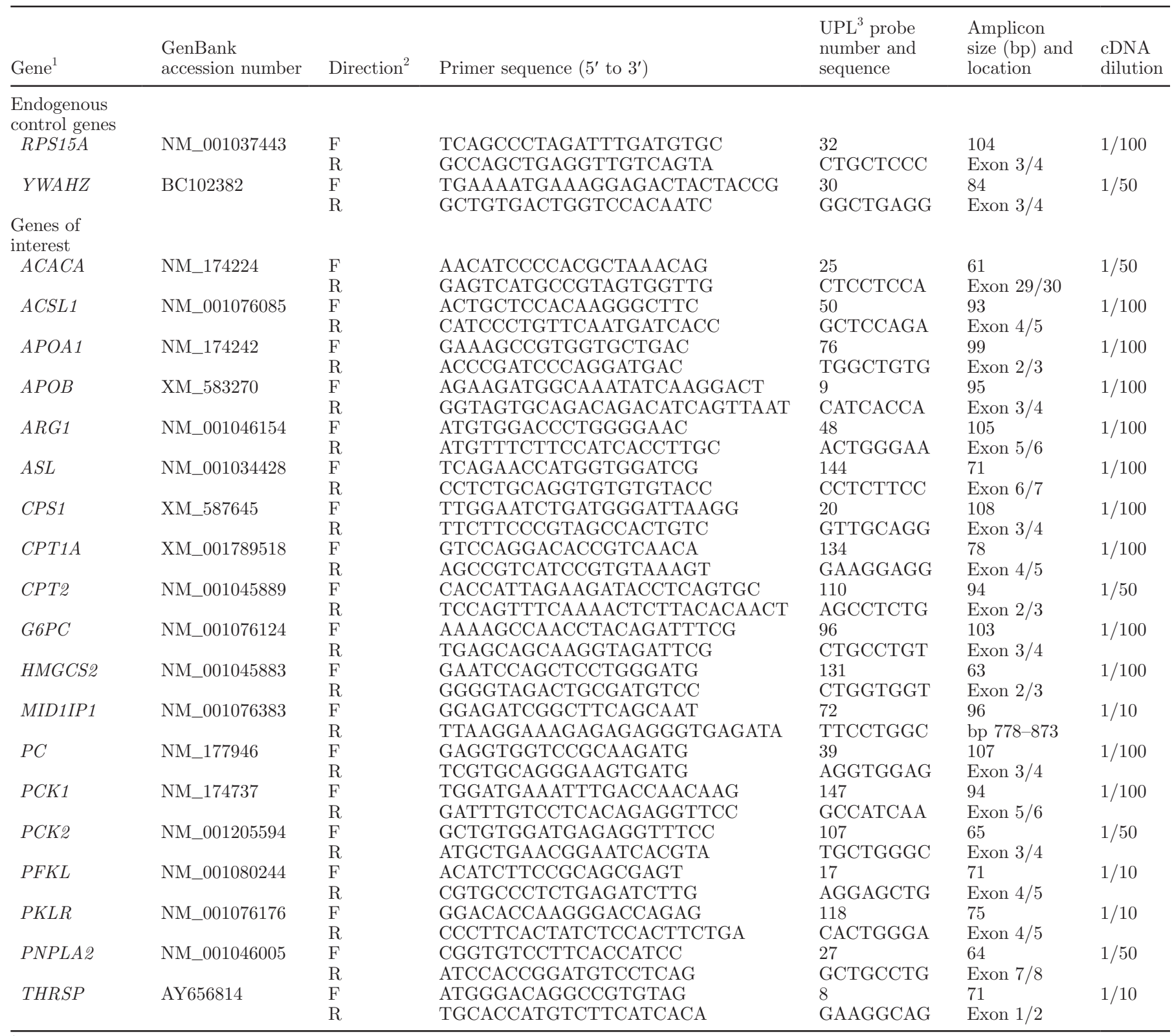

${ }^{1} R P S 15 A=$ ribosomal protein $\mathrm{S} 15 \mathrm{a} ; Y W A H Z=$ tyrosine 3-monooxygenase/tryptophan 5-monooxygenase activation protein, zeta polypeptide; $A C A C A=$ acetyl-CoA carboxylase $\alpha ; A C S L 1=$ acyl-CoA synthetase long-chain family member $1 ; A P O A 1=$ apolipoprotein A-I; $A P O B=$ apolipoprotein B: $A R G 1=$ arginase, liver; $A S L=$ argininosuccinate lyase; $C P S 1=$ carbamoyl-phosphate synthase 1 , mitochondrial; $C P T 1 A$ $=$ carnitine palmitoyltransferase $1 \mathrm{~A} ; C P T 2=$ carnitine palmitoyltransferase $2 ; G 6 P C=$ glucose-6-phosphatase, catalytic subunit; HMGCS2 $=3$-hydroxy-3-methylglutaryl-CoA synthase 2 , mitochondrial; MID1IP1 = MID1 interacting protein $1 ; P C=$ pyruvate carboxylase; $P C K 1=$ phosphoenolpyruvate carboxykinase 1 (soluble); $P C K 2=$ phosphoenolpyruvate carboxykinase 2 (mitochondrial); $P F K L=$ phosphofructokinase, liver; $P K L R=$ pyruvate kinase, liver and RBC; PNPLA2 = patatin-like phospholipase domain containing 2; THRSP = thyroid hormone responsive.

${ }^{2} \mathrm{~F}=$ forward; $\mathrm{R}=$ reverse

${ }^{3} \mathrm{UPL}=$ Universal Probe Library.

be used for each gene (Hellemans et al., 2007). Triplicate measurements were performed for all samples, and standard curves with standard deviations of $<0.15$ cycles were used for quantitation. Assays were tested for specificity by running an agarose gel of the PCR products to ensure amplicon specificity and length. The efficiency of each assay was between 1.91 and 1.97.

The Roche LightCycler 480 software was used to analyze gene expression using relative standard curve second-derivative maximum analysis. A 6-point stan- 
dard curve of serial cDNA dilutions was used, ranging from $3.33 \mathrm{e}^{-1}$ to $1.37 \mathrm{e}^{-3}$. Endogenous control genes were tested across all samples and their suitability determined using NormFinder and GeNorm (Vandesompele et al., 2002; Andersen et al., 2004a); RPS15A and $Y W A H Z$ were the 2 most stably expressed genes). The Roche LightCycler 480 Software was then used to perform advanced relative quantification analysis of gene expression using the normalization factor of the 2 endogenous control genes (RPS15A and YWAHZ). The geometric mean of the inter-run calibrators was calculated for each plate and applied to each sample.

\section{Calculations and Statistical Analysis}

Data from plasma insulin and each gene were $\log _{10^{-}}$ transformed before analysis due to their heterogeneity of variance. Data were then analyzed with a repeatedmeasures analysis as a mixed model (GenStat11.1; VSN International, Hemel Hempstead, UK). Because significant interactions were observed with time, data were then analyzed at wk 1 and 3 as a mixed model fitted with REML in GenStat, with treatments and contrasts to test milking frequency as a fixed effect, with cow as a random effect. At wk 6 and 9, the mixed model also included duration and the milking frequency by duration interactions as fixed effects.

Data are presented as means and standard error of the difference between the means (SED) for each treatment and time point. Plasma insulin was back-transformed for presentation. When no significant duration effects or milking frequency by duration interactions were detected, only main effects are presented. Differences in data were considered significant when $P<0.05$ and declared a trend when $P<0.10$.

\section{RESULTS}

\section{Milk Production, BCS, Plasma Hormone, and Metabolite Measurements}

Milk production measures and BCS are described in Phyn et al. (2011); however, relevant data at wk 1, 3, 6 , and 9 are presented in Table 2 . In brief, daily milk and ECM yields were greater at all 4 time points in cows milked $3 \times$ postpartum relative to those milked $1 \times$; however, although milk yield was also greater at wk 3 in cows milked $3 \times$ relative to $2 \times$, and tended to be greater at wk $6(P=0.08)$ and wk $9(P=0.07)$, this effect was not detected for ECM yields because of lower milk fat and protein contents (data not presented; Phyn et al., 2011). Furthermore, cows milked $1 \times$ postpartum had lower yields of milk and ECM at wk 1,3 , and 6 compared with cows milked $2 \times$. At wk
6 , we observed milking frequency by duration interactions, as cows that remained on $1 \times$ milking for $6 \mathrm{wk}$ had lower milk and ECM yields relative to cows milked $1 \times$ for 3 wk. Energy-corrected milk yields remained lower at wk 9 in cows previously milked $1 \times$ relative to $2 \times$, but this negative carryover response was not affected by the duration of reduced milking frequency following parturition.

Body condition score at wk 1 postpartum was lower in cows milked $3 \times$ relative to those milked $2 \times$. Cows milked $3 \times$ also had a lower BCS at wk 3 postpartum relative to cows milked $1 \times$ and tended $(P=0.06)$ to have a lower BCS relative to cows milked $2 \times$. By 6 wk, all cows milked $1 \times$ had a greater BCS than cows milked $2 \times$ or $3 \times$; however, a trend $(P=0.07)$ for a milking frequency $\times$ duration interaction indicated that differences were greatest for cows milked $1 \times$ for 6 wk postpartum.

Plasma concentrations of insulin, glucose, and NEFA are also presented in Table 2. Plasma NEFA concentrations at wk 1 were greater in cows milked $3 \times$ compared with those milked $2 \times$. Concentrations of NEFA in cows milked $1 \times$ postpartum were lower at wk 3 and tended $(P=0.06)$ to be lower at wk 6 relative to cows milked $2 \times$. Glucose concentrations were reduced in cows milked $3 \times$ at wk 1 relative to cows milked $2 \times$; however, glucose and insulin concentrations were greater at wk 1 and 3 in cows milked $1 \times$. At wk 6 , milking frequency $x$ duration interactions indicated that cows milked $1 \times$ for 6 wk continued to have greater glucose and tended $(P=0.07)$ to have greater insulin than cows milked $2 \times$. At wk 9, glucose concentrations were still greater and insulin tended $(P=0.09)$ to be greater in cows previously milked $1 \times$ relative to cows previously milked $3 \times$.

\section{Hepatic Gene Expression}

We detected no effects of duration or interactions between milking frequency and duration on hepatic gene expression; therefore, the main effects of milking frequency on hepatic gene expression are presented in Table 3.

Lipolysis and $\boldsymbol{\beta}$-Oxidation. At wk 1 and 3 postpartum, expression of patatin-like phospholipase domaincontaining protein 2 (PNPLA2) tended ( $P=0.09$ and $P=0.08)$ to be less in cows milked $1 \times$ compared with $2 \times$. At wk 1 postpartum, carnitine palmitoyltransferase $(C P T) 2$ expression was also lower in cows milked $1 \times$ compared with $2 \times$. At wk 3 postpartum, expression of acyl-CoA synthetase long-chain family member 1 (ACSL1) was greater in cows milked $3 \times$ compared with $1 \times$, and expression of $C P T 1 A$ expression in cows milked $1 \times$ was lower relative to those milked $3 \times$. At 3 wk postpartum, 3-hydroxy-3-methylglutaryl-CoA syn- 
Table 2. Effect of milking frequency (MF) on milk production, BCS, and plasma concentrations of hormones and metabolites in cows milked once daily for 3 or 6 wk immediately postpartum $(1 \times, \mathrm{n}=60)$, twice daily for the duration of lactation $(2 \times, \mathrm{n}=30)$, or thrice daily for 3 or 6 wk immediately postpartum $(3 \times$, $\mathrm{n}=60)$

\begin{tabular}{|c|c|c|c|c|c|c|c|c|c|c|c|}
\hline \multirow[b]{2}{*}{$\begin{array}{l}\text { Variable } \\
\text { and week }\end{array}$} & \multicolumn{5}{|c|}{ Treatment } & \multirow[b]{2}{*}{$\mathrm{SED}^{2}$} & \multicolumn{5}{|c|}{$P$-value } \\
\hline & $\begin{array}{c}1 \times \\
6 \mathrm{wk}\end{array}$ & $\begin{array}{c}1 \times \\
3 \mathrm{wk}\end{array}$ & $2 \times$ & $\begin{array}{c}3 \times \\
3 \mathrm{wk}\end{array}$ & $\begin{array}{c}3 \times \\
6 \mathrm{wk}\end{array}$ & & $\begin{array}{c}1 \times \\
\text { vs. } 2 \times\end{array}$ & $\begin{array}{c}2 \times \\
\text { vs. } 3 \times\end{array}$ & $\begin{array}{c}1 \times \\
\text { vs. } 3 \times\end{array}$ & Duration & $\begin{array}{c}\mathrm{MF} \times \\
\text { duration }\end{array}$ \\
\hline \multicolumn{12}{|c|}{ Milk (kg/d) } \\
\hline 1 & 16.2 & 17.0 & 20.0 & 21.2 & 20.4 & 0.9 & $<0.001$ & 0.34 & $<0.001$ & & \\
\hline 3 & 19.7 & 21.0 & 23.9 & 26.2 & 26.0 & 0.9 & $<0.001$ & $<0.01$ & $<0.001$ & & \\
\hline 6 & 20.5 & 24.9 & 25.9 & 26.9 & 28.3 & 1.1 & $<0.001$ & 0.08 & $<0.001$ & 0.05 & $<0.001$ \\
\hline 9 & 25.4 & 26.0 & 26.8 & 28.6 & 28.4 & 1.1 & 0.25 & 0.07 & $<0.001$ & 0.60 & 0.80 \\
\hline \multicolumn{12}{|c|}{$\operatorname{ECM}(\mathrm{kg} / \mathrm{d})$} \\
\hline 1 & 19.0 & 19.9 & 23.9 & 24.0 & 23.9 & 1.2 & $<0.001$ & 0.97 & $<0.001$ & & \\
\hline 3 & 21.3 & 23.3 & 27.0 & 27.6 & 27.5 & 1.1 & $<0.001$ & 0.55 & $<0.001$ & & \\
\hline 6 & 21.3 & 26.4 & 28.2 & 28.0 & 28.1 & 1.1 & $<0.001$ & 0.88 & $<0.001$ & $<0.01$ & $<0.01$ \\
\hline 9 & 26.3 & 27.5 & 29.1 & 29.6 & 29.6 & 1.1 & $<0.05$ & 0.58 & $<0.001$ & 0.48 & 0.46 \\
\hline \multicolumn{12}{|l|}{$\mathrm{BCS}^{3}$} \\
\hline 1 & 4.7 & 4.8 & 4.8 & 4.6 & 4.6 & 0.11 & 0.42 & $<0.05$ & 0.14 & & \\
\hline 3 & 4.6 & 4.6 & 4.5 & 4.4 & 4.3 & 0.11 & 0.20 & 0.06 & $<0.001$ & & \\
\hline 6 & 4.7 & 4.6 & 4.4 & 4.5 & 4.3 & 0.12 & $<0.05$ & 0.60 & $<0.001$ & 0.87 & 0.07 \\
\hline $9 / 10$ & 4.6 & 4.6 & 4.5 & 4.6 & 4.5 & 0.12 & 0.19 & 0.69 & 0.26 & 0.41 & 0.84 \\
\hline \multicolumn{12}{|c|}{ Glucose (mmol/L) } \\
\hline 1 & 3.81 & 3.78 & 3.58 & 3.42 & 3.34 & 0.10 & $<0.05$ & $<0.05$ & $<0.001$ & & \\
\hline 3 & 3.98 & 3.98 & 3.56 & 3.46 & 3.39 & 0.10 & $<0.001$ & 0.12 & $<0.001$ & & \\
\hline 6 & 4.17 & 3.89 & 3.80 & 3.82 & 3.77 & 0.08 & $<0.001$ & 0.92 & $<0.001$ & 0.05 & $<0.01$ \\
\hline 9 & 4.04 & 4.16 & 4.06 & 4.07 & 3.89 & 0.08 & 0.58 & 0.25 & $<0.05$ & $<0.05$ & 0.53 \\
\hline \multicolumn{12}{|c|}{ Insulin $^{4}\left(\log _{10} \mu \mathrm{U} / \mathrm{mL}\right)$} \\
\hline 1 & $0.39(2.79)$ & $0.46(3.19)$ & $0.27(2.15)$ & $0.20(1.77)$ & $0.18(1.84)$ & 0.06 & $<0.01$ & 0.14 & $<0.001$ & & \\
\hline 3 & $0.38(2.73)$ & $0.43(3.51)$ & $0.16(1.52)$ & $0.23(1.81)$ & $0.15(1.56)$ & 0.05 & $<0.001$ & 0.55 & $<0.001$ & & \\
\hline 6 & $0.44(3.36)$ & $0.34(2.38)$ & $0.31(2.21)$ & $0.29(2.12)$ & $0.26(1.98)$ & 0.05 & 0.06 & 0.45 & $<0.01$ & 0.30 & 0.07 \\
\hline 9 & $0.37(2.69)$ & $0.47(3.38)$ & $0.35(2.46)$ & $0.39(2.63)$ & $0.32(2.37)$ & 0.05 & 0.14 & 0.92 & 0.09 & $<0.05$ & 0.69 \\
\hline \multicolumn{12}{|c|}{ NEFA (mmol/L) } \\
\hline 1 & 0.93 & 0.91 & 1.03 & 1.37 & 1.27 & 0.11 & 0.14 & $<0.01$ & $<0.001$ & & \\
\hline 3 & 0.80 & 0.83 & 1.17 & 1.24 & 1.14 & 0.11 & $<0.001$ & 0.79 & $<0.001$ & & \\
\hline 6 & 0.61 & 0.73 & 0.75 & 0.85 & 0.80 & 0.08 & 0.06 & 0.55 & $<0.001$ & 0.06 & 0.27 \\
\hline 9 & 0.43 & 0.48 & 0.45 & 0.49 & 0.49 & 0.10 & 0.50 & 0.12 & 0.26 & 0.37 & 0.62 \\
\hline
\end{tabular}

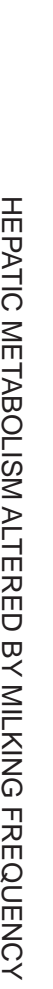

${ }^{1}$ Cows milked $1 \times$ or $3 \times$ were switched to $2 \times$ milking after 3 or 6 wk on the alternative milking frequency.

$\stackrel{2}{\stackrel{2}{\Phi}} \quad{ }^{2} \mathrm{SED}=$ standard error of the difference between means.

ก ${ }^{3}$ According to 10-point scale (Roche et al., 2004).

Insulin data were $\log _{10}$-transformed for analysis (back-transformed values in parentheses). 
Table 3. Effect of milking frequency on the mRNA expression of key genes involved in hepatic metabolism in cows milked once daily for 3 or 6 wk immediately postpartum $(1 \times, \mathrm{n}=24)$, twice daily for the duration of lactation $(2 \times, \mathrm{n}=12)$, or thrice daily for 3 to 6 wk immediately postpartum $(3 \times, \mathrm{n}=24)^{1}$

\begin{tabular}{|c|c|c|c|c|c|c|c|}
\hline $\mathrm{Gene}^{2}$ and week & \multicolumn{3}{|c|}{ Milking frequency } & $\mathrm{SED}^{3}$ & \multicolumn{3}{|c|}{$P$-value ${ }^{4}$} \\
\hline \multicolumn{8}{|c|}{$\beta$-Oxidation, ketogenesis and lipolysis } \\
\hline 1 & 0.46 & 0.45 & 0.52 & 0.05 & 0.82 & 0.48 & 0.65 \\
\hline 3 & 0.40 & 0.43 & 0.50 & 0.05 & 0.53 & 0.14 & $<0.05$ \\
\hline 6 & 0.36 & 0.39 & 0.32 & 0.05 & 0.63 & 0.27 & 0.42 \\
\hline 1 & 0.39 & 0.41 & 0.39 & 0.07 & 0.81 & 0.79 & 0.99 \\
\hline 3 & 0.36 & 0.43 & 0.44 & 0.04 & 0.06 & 0.79 & $<0.05$ \\
\hline 6 & 0.32 & 0.35 & 0.36 & 0.05 & 0.43 & 0.78 & 0.19 \\
\hline 9 & 0.31 & 0.31 & 0.34 & 0.04 & 1.00 & 0.49 & 0.40 \\
\hline \multicolumn{8}{|l|}{ CPT2 } \\
\hline 1 & 0.23 & 0.31 & 0.31 & 0.03 & $<0.05$ & 0.10 & 0.32 \\
\hline 3 & 0.23 & 0.27 & 0.26 & 0.03 & 0.16 & 0.92 & 0.13 \\
\hline 6 & 0.50 & 0.52 & 0.47 & 0.05 & 0.79 & 0.40 & 0.47 \\
\hline 9 & 0.48 & 0.51 & 0.54 & 0.05 & 0.42 & 0.35 & $<0.05$ \\
\hline \multicolumn{8}{|l|}{ PNPLA2 } \\
\hline 1 & 0.26 & 0.37 & 0.33 & 0.07 & 0.09 & 0.25 & 0.55 \\
\hline 3 & 0.28 & 0.35 & 0.33 & 0.04 & 0.08 & 0.57 & 0.16 \\
\hline 6 & 0.29 & 0.33 & 0.23 & 0.05 & 0.43 & 0.57 & 0.81 \\
\hline 9 & 0.32 & 0.30 & 0.33 & 0.04 & 0.55 & 0.38 & 0.71 \\
\hline \multirow{2}{*}{\multicolumn{8}{|c|}{ Fatty acid synthesis }} \\
\hline & & & & & & & $A C A C A$ \\
\hline 1 & 0.31 & 0.32 & 0.37 & 0.08 & 0.88 & 0.89 & 0.77 \\
\hline 3 & 0.43 & 0.42 & 0.38 & 0.05 & 0.96 & 0.37 & 0.26 \\
\hline 6 & 0.48 & 0.56 & 0.44 & 0.05 & 0.12 & $<0.05$ & 0.28 \\
\hline 9 & 0.46 & 0.43 & 0.48 & 0.05 & 0.49 & 0.24 & 0.54 \\
\hline \multicolumn{8}{|l|}{ MID1IP1 } \\
\hline \multicolumn{8}{|l|}{ THRSP } \\
\hline \multicolumn{8}{|l|}{ Lipid transport } \\
\hline $\begin{array}{l}A P O A I \\
1\end{array}$ & 0.79 & 0.90 & 0.94 & 0.14 & 0.34 & 0.90 & 0.40 \\
\hline 3 & 0.65 & 0.80 & 0.74 & 0.08 & 0.05 & 0.54 & 0.12 \\
\hline 6 & 0.50 & 0.66 & 0.60 & 0.08 & $<0.05$ & 0.73 & 0.05 \\
\hline 9 & 0.50 & 0.49 & 0.51 & 0.09 & 0.91 & 0.75 & 0.79 \\
\hline$A P O B$ & & & & & & & \\
\hline 1 & 0.26 & 0.35 & 0.32 & 0.06 & 0.09 & 0.29 & 0.47 \\
\hline 3 & 0.29 & 0.34 & 0.25 & 0.04 & 0.25 & $<0.05$ & 0.30 \\
\hline 6 & 0.31 & 0.32 & 0.29 & 0.04 & 0.91 & 0.62 & 0.63 \\
\hline 9 & 0.34 & 0.33 & 0.37 & 0.04 & 0.84 & 0.26 & 0.26 \\
\hline $\begin{array}{l}\text { Gluconeogenesis } \\
\text { G6PC }\end{array}$ & & & & & & & \\
\hline $\begin{array}{l}G 6 P C \\
1\end{array}$ & & & & & & & \\
\hline $\begin{array}{l}1 \\
3\end{array}$ & 0.37 & 0.45 & 0.39 & 0.05 & 0.05 & 0.24 & 0.40 \\
\hline $\begin{array}{l}3 \\
6\end{array}$ & 0.37 & 0.45 & 0.38 & 0.04 & $<0.05$ & 0.09 & 0.78 \\
\hline 6 & 0.33 & 0.41 & 0.34 & 0.05 & 0.10 & 0.19 & 0.72 \\
\hline 9 & 0.33 & 0.33 & 0.37 & 0.05 & 0.93 & 0.46 & 0.32 \\
\hline$P C$ & & & & & & & \\
\hline 1 & 1.12 & 1.05 & 0.88 & 0.24 & 0.73 & 0.42 & 0.26 \\
\hline
\end{tabular}


Table 3 (Continued). Effect of milking frequency on the mRNA expression of key genes involved in hepatic metabolism in cows milked once daily for 3 or 6 wk immediately postpartum $(1 \times, \mathrm{n}=24)$, twice daily for the duration of lactation $(2 \times, \mathrm{n}=12)$, or thrice daily for 3 to 6 wk immediately postpartum $(3 \times, \mathrm{n}=24)^{1}$

\begin{tabular}{|c|c|c|c|c|c|c|c|}
\hline $\mathrm{Gene}^{2}$ and week & \multicolumn{3}{|c|}{ Milking frequency } & $\mathrm{SED}^{3}$ & \multicolumn{3}{|c|}{$P$-value ${ }^{4}$} \\
\hline 3 & 0.93 & 0.96 & 1.06 & 0.16 & 0.86 & 0.51 & 0.31 \\
\hline 9 & 0.79 & 0.64 & 0.84 & 0.16 & 0.34 & 0.18 & 0.59 \\
\hline \multicolumn{8}{|l|}{$P C K 1$} \\
\hline 1 & 0.38 & 0.48 & 0.52 & 0.07 & 0.10 & 0.75 & 0.05 \\
\hline \multicolumn{8}{|l|}{ PCK2 } \\
\hline 1 & 0.42 & 0.52 & 0.64 & 0.06 & 0.06 & $<0.05$ & 0.87 \\
\hline 3 & 0.32 & 0.35 & 0.32 & 0.05 & 0.51 & 0.58 & 0.91 \\
\hline 6 & 0.34 & 0.36 & 0.33 & 0.06 & 0.75 & 0.71 & 0.94 \\
\hline 9 & 0.36 & 0.28 & 0.39 & 0.05 & 0.09 & $<0.05$ & 0.37 \\
\hline \multicolumn{8}{|l|}{ Glycolysis } \\
\hline \multicolumn{8}{|l|}{$P K L R$} \\
\hline 1 & 0.36 & 0.41 & 0.39 & 0.06 & 0.37 & 0.32 & 0.93 \\
\hline 3 & 0.35 & 0.36 & 0.33 & 0.05 & 0.85 & 0.55 & 0.63 \\
\hline 6 & 0.33 & 0.42 & 0.33 & 0.05 & 0.06 & 0.09 & 0.88 \\
\hline 9 & 0.37 & 0.29 & 0.42 & 0.05 & 0.12 & $<0.05$ & 0.19 \\
\hline \multicolumn{8}{|l|}{ Urea metabolism } \\
\hline \multicolumn{8}{|l|}{$A R G 1$} \\
\hline 1 & 0.49 & 0.56 & 0.53 & 0.08 & 0.29 & 1.00 & 0.29 \\
\hline 3 & 0.39 & 0.44 & 0.42 & 0.06 & 0.46 & 0.82 & 0.55 \\
\hline 6 & 0.47 & 0.49 & 0.50 & 0.07 & 0.82 & 0.95 & 0.73 \\
\hline 9 & 0.53 & 0.55 & 0.57 & 0.07 & 0.69 & 0.73 & 0.38 \\
\hline \multicolumn{8}{|l|}{$A S L$} \\
\hline 1 & 0.82 & 1.03 & 0.91 & 0.08 & $<0.01$ & 0.10 & 0.10 \\
\hline 3 & 1.02 & 1.16 & 1.03 & 0.07 & 0.06 & 0.13 & 0.71 \\
\hline
\end{tabular}

${ }^{1}$ Cows milked $1 \times$ or $3 \times$ were switched to $2 \times$ milking after 3 or 6 wk on the alternative milking frequency. Data are expressed as log ${ }_{10}$-transformed arbitrary units normalized to the expression of ribosomal protein S15a and tyrosine 3-monooxygenase/tryptophan 5-monooxygenase activation protein, zeta polypeptide.

${ }^{2} A C A C A=$ acetyl-CoA carboxylase $\alpha ; A C S L 1=$ acyl-CoA synthetase long-chain family member $1 ; A P O A 1=$ apolipoprotein A-I; $A P O B=$ apolipoprotein B; $A R G 1=$ arginase, liver; $A S L=$ argininosuccinate lyase; $C P S 1=$ carbamoyl-phosphate synthase 1 , mitochondrial; $C P T 1 A=$ carnitine palmitoyltransferase 1a; $C P T 2=$ carnitine palmitoyltransferase $2 ; G 6 P C=$ glucose-6-phosphatase, catalytic subunit; $H M G C S 2=3$-hydroxy-3-methylglutaryl-CoA synthase 2, mitochondrial; $M I D 1 I P 1=$ MID1 interacting protein $1 ; P C=$ pyruvate carboxylase; $P C K 1=$ phosphoenolpyruvate carboxykinase 1 (soluble); $P C K 2=$ phosphoenolpyruvate carboxykinase 2 (mitochondrial); $P F K L=$ phosphofructokinase, liver $P K L R=$ pyruvate kinase, liver and RBC; PNPLA2 = patatin-like phospholipase domain containing 2 ; THRSP $=$ thyroid hormone responsive. ${ }^{3} \mathrm{SED}=$ standard error of the difference

${ }^{4}$ No duration effects or interactions were observed between milking frequency and duration; hence, only the main effects of milking frequency are presented.

thase 2 (mitochondrial; HMGCS2) expression was lower in cows milked $1 \times$ compared with $2 \times$, and, at 9 wk postpartum, it was greater in cows previously milked $3 \times$ relative to $1 \times$.

Lipogenesis. At wk 3 postpartum, cows milked $1 \times$ had a greater expression of thyroid hormone responsive
$(T H R S P)$ relative to those milked $3 \times$. At wk 6 postpartum, THRSP expression was also greater in cows milked $1 \times$ relative to $3 \times$, whereas cows milked $3 \times$ had lower expression of $A C A C A$ compared with cows milked $2 \times$, and tended to have lower $(P=0.07)$ expression of MID1 interacting protein 1 (MID1IP1) expression 
compared with cows milked $1 \times$. By wk 9 postpartum, we found no differences in lipogenic gene expression between MF treatments.

Lipid Transport. Cows milked $1 \times$ had lower expression of apolipoprotein $(A P O) A 1$ relative to $2 \times$ at both wk 3 and 6 postpartum and relative to $3 \times$ at wk 6 postpartum. At wk 1 postpartum, $A P O B$ expression tended $(P=0.09)$ to be lower in cows milked $1 \times$ and, at wk 3 postpartum, it was lower in cows milked $3 \times$ compared with $2 \times$.

Gluconeogenesis. At wk 1 postpartum, expression of mitochondrial phosphoenolpyruvate carboxykinase 2 $(P C K 2)$ and glucose-6-phosphatase, catalytic subunit ( $G 6 P C)$ tended ( $P=0.06$ and $P=0.05$; respectively) to be lower in cows milked $1 \times$ relative to $2 \times$, and $P C K 1$ expression tended to be lower in cows milked $1 \times$ relative to $3 \times(P=0.05)$. Expression of $P C K 2$ was lower in cows milked $3 \times$ relative to those milked $2 \times$.

At wk 3 postpartum, cows milked $1 \times$ had lower $P C K 1$ expression compared with $2 \times$. Expression of $G 6 P C$ at wk 3 postpartum was lower and at wk 6 tended to be lower $(P=0.10)$ in cows milked $1 \times$ than in cows milked $2 \times$.

At wk 9, PCK1 expression was greater in cows previously milked $3 \times$ relative to those previously milked $1 \times$, whereas $P C K 2$ was greater in cows previously milked $3 \times$, and tended $(P=0.09)$ to be greater in cows previously milked $1 \times$, relative to $2 \times$.

Glycolysis. At wk 1 postpartum, expression of phosphofructokinase $(P F K L)$ tended $(P=0.07)$ to be reduced in cows milked $1 \times$ compared with $2 \times$. At wk 6 postpartum, liver and red blood cell pyruvate kinase $(P K L R)$ expression tended to be lower in cows milked $1 \times$ or $3 \times$ compared with $2 \times(P=0.06$ and $P=0.09$; respectively), with similar expression in cows milked $1 \times$ and $3 \times$. At wk 9 postpartum, cows previously milked $3 \times$ had greater expression of both genes compared with cows milked $2 \times$. Cows previously milked $1 \times$ tended $(P$ $=0.06)$ to have greater expression of $P F K L$ compared with cows milked $2 \times$.

Urea Metabolism. Argininosuccinate lyase $(A S L)$ expression was lower at wk 1 , and tended $(P=0.06)$ to be lower at wk 3 in cows milked $1 \times$ compared with $2 \times$. At wk 9 postpartum, expression of both $A S L$ and carbamoyl phosphate synthase 1 (CPS1) was greater in cows previously milked $3 \times$ than in cows previously milked $1 \times$.

\section{DISCUSSION}

Alterations to MF during early lactation affected liver metabolism, consistent with changes in the energy requirements for milk production (Phyn et al., 2011). Hepatic gene expression profiles indicated that cows milked $1 \times$ downregulated pathways necessary for milk production, such as gluconeogenesis, whereas cows milked $3 \times$ limited lipoprotein synthesis and, therefore, lipid transport. Interestingly, we observed no interactions between MF and duration, which indicates that during early lactation, changes to MF have the greatest effect on hepatic metabolism in the first 3 wk of lactation.

\section{Milking Cows 1× Decreases Pathways of NEFA Utilization}

Milking cows $1 \times$ elicited a shift in hepatic gene expression indicative of a reduced capacity for FA oxidation, and greater lipogenesis. Once FA are absorbed by the hepatocytes they are activated by $A C S L 1$, and transported into the mitochondria by $C P T 1 A$ and $C P T 2$ for $\beta$-oxidation (Nguyen et al., 2008). Expression of these 3 genes, and the gene involved in ketogenesis, HMGCS2, was lower in cows milked $1 \times$ at various times during the reduced milking frequency period. Plasma NEFA concentrations were lower in cows milked $1 \times$ relative to $2 \times$; therefore, it is likely that hepatic uptake of NEFA is also reduced, limiting the demand for FA oxidation. Inhibition of $\beta$-oxidation has been suggested to be a result of growth hormone (GH) signaling in murine liver (Vijayakumar et al., 2010). Growth hormone receptor $1 \mathrm{~A}$ transcription was greater in cows milked $1 \times$ (our unpublished data); therefore, less uncoupling of the GH:IGF1 axis and potentially greater GH signaling may occur in these cows. Transcriptional increases in THRSP and MID1IP1 expression indicate increased lipogenesis (Wu et al., 2013) in cows milked $1 \times$ relative to those milked $3 \times$, which may also be a result of increased GH signaling (Vijayakumar et al., 2010).

Other actions of GH include inhibition of hepatic lipolysis (Vijayakumar et al., 2010). The protein encoded by PNPLA2 hydrolyzes the first FA from a triacylglyceride and transcription of this gene was lower at both 1 and 3 wk postpartum in cows milked $1 \times$ relative to cows milked $2 \times$, indicating reduced intrahepatic lipolysis. Stored triacylglycerides are exported from the liver in very low density lipoproteins (VLDL), which contain APOB (Ikonen, 2008). Although triacylglyceride synthesis was not measured in the present study, $A P O B$ transcription was reduced in cows milked $1 \times$. Synthesis of APOB is necessary for the formation of the triacylglyceride-enriched VLDL (Ikonen, 2008) and rate-limiting for VLDL secretion in cows (Uchida et al., 1992). Therefore, lower $A P O B$ mRNA may indicate lower VLDL synthesis and subsequent triacylglyceride output (Gruffat et al., 1996). However, without triacylglyceride concentrations from the liver of these animals, we cannot confirm that reduced $A P O B$ and 
PNPLA2 transcription is a result of lower triacylglyceride concentrations in cows milked $1 \times$. Finally, low NEFA concentrations resulting from greater transcription of lipogenic genes in adipose tissue will limit the availability of FA for uptake by the liver, thereby reducing the requirement for $\beta$-oxidation and triacylglyceride export. To summarize, cows milked $1 \times$ have lower NEFA concentrations and therefore, appear to have a lesser requirement for hepatic adaptations such as $\beta$-oxidation and triacylglyceride export than cows milked more frequently. However, further research is required to determine if a net change in lipid uptake and storage occurs in these cows.

\section{Milking 1× Decreases Glucose Cycling}

Hepatic gluconeogenic gene expression was downregulated during the first 3 wk postpartum in cows milked $1 \times$, concomitant with greater plasma glucose concentrations. Glucose is synthesized in the liver from ruminally-derived propionate and lactate (Aschenbach et al., 2010). In this gluconeogenic process, lactate is converted to pyruvate and then to oxaloacetate by pyruvate carboxylase $(\mathrm{PC})$. In turn, oxaloacetate is converted to phosphoenolpyruvate by PCK1 in the cytosol or PCK2 in the mitochondria, which, via intermediates, is converted to glucose-6-phosphate. The final step in gluconeogenesis, the production of glucose, is catalyzed by G6PC (Newsholme and Leech, 1988). Expression of the key enzymes $P C K 1, P C K 2$, and $G 6 P C$ were all reduced in cows milked $1 \times$; however, $P C$ expression was not affected by postpartum MF. Hence, it is the later steps of gluconeogenesis, rather than the production of oxaloacetate from pyruvate, that are downregulated by milking cows less frequently.

Gluconeogenesis in ruminants is related to milk production due to the mammary gland's demand for glucose to synthesize lactose. Milk production was reduced in cows milked $1 \times$ postpartum (Phyn et al., 2011) and, consistent with this, circulating glucose and insulin concentrations were greater; this may have triggered a coordinated reduction in hepatic glucose production. Lower production of de novo glucose from propionate in cows milked $1 \times$ may have further improved energy status by increasing the oxaloacetate pool for energy production via the tricarboxylic acid cycle (White et al., 2011). This premise supports a reduced need for mobilization of lipid stores and $\beta$-oxidation of fatty acids as discussed previously. Interestingly, transcription of the key glycolytic enzymes, PFKL and PKLR, was also reduced in cows milked $1 \times$. Hepatic glycolysis is an anaerobic process by which glucose-6-phosphate is converted to pyruvate when cellular energy is limited
(Pilkis and Granner, 1992). Reduced transcription of PFKL and PKLR may be due to a reduced demand for energy production via the anaerobic breakdown of glucose-6-phosphate to pyruvate. However, the importance of these enzymes in ruminants may be low because of the drive for glucose export (Aschenbach et al., 2010). These results indicate that a reduced need for glucose to support milk lactose synthesis and mammary metabolism in cows milked $1 \times$ is accommodated by altered liver carbohydrate metabolism.

\section{Milking 3x also Decreases Glucose Synthesis}

Gluconeogenic and glycolytic gene expression was also reduced in the liver of cows milked $3 \times$; however, this effect was different from that reported in cows milked $1 \times$. Expression of $P C K 2$ and $G 6 P C$ was reduced but there were no effects on $P C$ or $P C K 1$ transcription. The decrease in $P C K 2$ and $G 6 P C$ expression without the decrease in $P C K 1$ may be due to the different regulation and roles of $P C K 1$ and $P C K 2$ in gluconeogenesis and triacylglyceride formation: $P C K 1$ is thought to be more suited for gluconeogenesis from amino acids and is thought to play roles in glycerol-3-phosphate production for triacylglyceride synthesis, as the gene is strongly regulated by the presence of gluconeogenic precursors (Millward et al., 2010). Similar PCK1 expression between cows milked $2 \times$ and those milked $3 \times$ indicates that comparable cytosolic gluconeogenesis occurred between these 2 groups. By comparison, PCK2 is believed to be required for gluconeogenesis from lactate, as the conversion of lactate in the mitochondria requires mitochondrial production of phosphoenolpyruvate (Aschenbach et al., 2010). Reduced PCK2 transcription during the first week postpartum in cows milked $3 \times$ instead of $2 \times$ may be due to a limited supply of lactate; or, as $P C$ expression was not altered, a limited supply of mitochondrial oxaloacetate. Although plasma glucose was lower, lactose concentration was also reduced in cows milked $3 \times$ compared with $2 \times$ (Phyn et al., 2011), which may indicate similar glucose production and utilization across these groups.

Hepatic G6PC transcription tended to be downregulated at 3 wk postpartum when cows were milked $3 \times$ instead of $2 \times$. Transcription of $G 6 P C$ can be inhibited by inflammatory markers, such as tumor necrosis factor- $\alpha$ and IL-6 (Hutton and O'Brien, 2009). Interestingly, nutritionally induced ketosis has been reported to result in the upregulation of $I L-6$ by approximately 3 -fold (Loor et al., 2007). Cows milked $3 \times$ were not clinically ketotic in this study; however, their greater NEB (Phyn et al., 2011) and liver stress may have increased production of this proinflammatory cytokine. 
Therefore, increased liver stress may be responsible for the reduced expression of $G 6 P C$ in cows milked $3 \times$; however, this premise is yet to be tested experimentally.

\section{Greater Glucose Cycling in Cows Previously Milked $1 \times$ or $3 x$}

Transcription of $P C K 2$ was upregulated in the liver of cows with altered postpartum MF (i.e., $1 \times$ or $3 \times$ vs. $2 \times$ ) after they were switched to $2 \times$ milking. For instance, $P C K 2$ expression at wk 9 postpartum was greater in cows previously milked $3 \times$ relative to those previously milked $2 \times$. The switch from $3 \times$ to $2 \times$ milking (at wk 3 or 6 postpartum) reduced daily milk yields in these animals, but production was still greater than that of cows milked $1 \times$ postpartum and slightly more than that of cows milked $2 \times$ from calving (Phyn et al., 2011). Therefore, greater $P C K 2$ transcription in cows milked $3 \times$ was likely due to their greater glucose requirements for lactose production. The switch from $3 \times$ to $2 \times$ milking would also reduce glucogenic precursor utilization for milk production by the mammary gland, which would make more precursors available for gluconeogenesis in the liver, particularly lactate, which PCK2 uses preferentially (Aschenbach et al., 2010). The greater PCK2 transcription relative to cows milked $2 \times$ indicated a greater capacity for gluconeogenesis from lactate in cows previously milked $3 \times$ and $1 \times$; cows previously milked $1 \times$ also had greater $P C K 2$ expression relative to $2 \times$ at wk 9 . Greater transcription of $P C K 2$ in cows previously milked $1 \times$ may indicate that gluconeogenesis from lactate was upregulated in response to an increased glucose demand by the mammary gland due to the increase in milk production when switched from $1 \times$ to $2 \times$ milking (Phyn et al., 2011).

This increase in gluconeogenesis in cows with altered postpartum MF was accompanied by an increase in transcription of glycolytic genes, indicating an increase in glucose cycling. Cows previously milked $1 \times$ or $3 \times$ had greater transcription of $P F K L$ and $P K L R$ at wk 9 postpartum, indicating greater glycolysis (Pilkis and Granner, 1992) than cows milked $2 \times$ from calving. Therefore, the switch to $2 \times$ milking may require greater pyruvate and acetyl-CoA production than necessary on $1 \times$ or $3 \times$ milking. Transcription of both $P F K L$ and $P K L R$ is enhanced by glucose and insulin in other mammals (Pilkis and Granner, 1992); however, due to the adaptations of the dairy cow to high milk production during early lactation, it is not known if this regulation is present. Additionally, glucose and insulin concentrations were not significantly different between cows milked $1 \times$ and $2 \times$ or between cows milked $2 \times$ and $3 \times$ by wk 9 postpartum. These results all indicate that the switch to $2 \times$ milking increases gluconeogenesis from lactate and increases glycolysis to meet demands for milk production changes.

\section{Carryover Effects of $1 \times$ or $3 \times$ Milking}

Milking cows $3 \times$ for 3 or 6 wk postpartum upregulated the expression of ureagenic genes after they were switched to $2 \times$, as cows previously milked $3 \times$ had greater transcription of $C P S 1$ and $A S L$ at wk 9 postpartum, compared with cows previously milked $1 \times$. Ammonia is produced through muscle glycolysis and once transported to the liver, is converted to nontoxic urea for excretion. Ammonia is catalyzed by CPS1 into carbamoyl phosphate, the first committed step of the urea cycle. Carbamoyl phosphate is converted to citrulline and then arginino-succinate before arginino-succinate is converted to arginine by ASL. This part of the cycle also produces fumarate. Arginine is finally converted to urea and ornithine by ARG1 (Morris, 2002). Increases in transcription of $C P S 1$ and $A S L$ in cows previously milked $3 \times$ relative to $1 \times$ without a concomitant increase in $A R G 1$ indicate that the production of fumarate may be driving the urea cycle rather than detoxification of ammonium. Fumarate can be converted, via malate, to oxaloacetate, the substrate of $P C K 1$, the expression of which was also upregulated at wk 9 in cows previously milked $3 \times$ relative to $1 \times$. An increase in gluconeogenic precursors in the form of malate may have positively regulated $P C K 1$ transcription. These results indicate that greater $C P S 1, A S L$, and $P C K 1$ transcription in cows previously milked $3 \times$ relative to $1 \times$ may result in greater glucose production from amino acids. The switch from $3 \times$ to $2 \times$ milking reduced daily milk yields in these animals (Phyn et al., 2011); therefore, it is plausible that the switch from $3 \times$ to $2 \times$ milking would reduce glucose requirements for milk production by the mammary gland, which would make more precursors available for gluconeogenesis in the liver.

The final gene differentially expressed at wk 9 postpartum between cows previously milked $3 \times$ and $1 \times$ was $H M G C S 2$, which is an essential enzyme in the production of ketone bodies when acetyl-CoA is in excess. The decrease in milk production when cows were switched from $3 \times$ to $2 \times$ milking may have resulted in excess acetyl-CoA production, which originated because it was either not required for the tricarboxylic acid cycle or because the tricarboxylic acid cycle was limited by reductions in other important intermediates such as oxaloacetate due to gluconeogenesis. The extra acetylCoA may drive ketogenesis; however, this is more likely to occur at the posttranscriptional level (Hegardt, 1999). Insulin concentrations tended to be lower in cows milked $1 \times$ relative to $3 \times$ at wk 9 , and HMGCS2 transcription is inhibited by insulin (Hegardt, 1999). 
Therefore, it is possible that if insulin concentrations were similar between cows previously milking at alternate frequencies, transcription of $H M G C S 2$ would also be similar. Milking $3 \times$ does have carryover effects on hepatic metabolism compared with cows previously milked $1 \times$. These changes in gene transcription are likely driven by a nutrient requirement or excess when the cows are milked $2 \times$.

\section{CONCLUSIONS}

Alternative MF for short periods immediately postpartum influenced hepatic metabolism. Cows milked $1 \times$ had lower glucose synthesis and lower FA oxidation relative to cows milked $2 \times$. Cows milked $3 \times$ also had lower glucose cycling and greater FA use for fuel compared with cows milked $2 \times$. After cows were switched to $2 \times$ milking, glucose cycling was greater in all cows previously milked more or less frequently than $2 \times$. As no differences were reported between cows allocated to the same MF for different durations, changes to MF during early lactation had the greatest effect on hepatic metabolism in the first 3 wk of lactation.

\section{ACKNOWLEDGMENTS}

The authors thank and acknowledge the statistical expertise of Barbara Dow (Dairy NZ, Hamilton, New Zealand) and all the help afforded by DairyNZ Lye Farm staff, especially Stuart Morgan for tissue biopsy sampling and animal measurements. This study was funded by New Zealand dairy farmers through DairyNZ Inc. and by the New Zealand Ministry of Business, Innovation, and Employment (MoBIE).

\section{REFERENCES}

Altschul, S. F., W. Gish, W. Miller, E. W. Myers, and D. J. Lipman. 1990. Basic local alignment search tool. J. Mol. Biol. 215:403-410.

Andersen, C. L., J. L. Jensen, and T. F. Ørntoft. 2004a. Normalization of real-time quantitative reverse transcription-PCR data: A model-based variance estimation approach to identify genes suited for normalization, applied to bladder and colon cancer data sets. Cancer Res. 64:5245-5250.

Andersen, J. B., N. C. Friggens, T. Larsen, M. Vestergaard, and K. L. Ingvartsen. 2004b. Effect of energy density in the diet and milking frequency on plasma metabolites and hormones in early lactation dairy cows. J. Vet. Med. A Physiol. Pathol. Clin. Med. 51:52-57. http://dx.doi.org/10.1111/j.1439-0442.2004.00605.x.

Aschenbach, J. R., N. B. Kristensen, S. S. Donkin, H. M. Hammon, and G. B. Penner. 2010. Gluconeogenesis in dairy cows: The secret of making sweet milk from sour dough. IUBMB Life 62:869-877. http://dx.doi.org/10.1002/iub.400.

Bar-Peled, U., E. Maltz, I. Bruckental, Y. Folman, Y. Kali, H. Gacitua, A. R. Lehrer, C. H. Knight, B. Robinzon, and H. Voet. 1995. Relationship between frequent milking or suckling in early lactation and milk production of high producing dairy cows. J. Dairy Sci. $78: 2726-2736$.

Bauman, D. E., and J. M. Elliot. 1983. Control of nutrient partitioning in lactating ruminants. Pages 437-468 in Biochemistry of Lacta- tion. T. B. Mepham, ed. Elsevier Inc., Amsterdam, the Netherlands.

Bell, A. W. 1995. Regulation of organic nutrient metabolism during transition from late pregnancy to early lactation. J. Anim. Sci. 73:2804-2819

Chagas, L. M., P. J. S. Gore, S. Meier, K. A. Macdonald, and G. A. Verkerk. 2007. Effect of monopropylene glycol on luteinizing hormone, metabolites, and postpartum anovulatory intervals in primiparous dairy cows. J. Dairy Sci. 90:1168-1175.

Gruffat, D., D. Durand, B. Graulet, and D. Bauchart. 1996. Regulation of VLDL synthesis and secretion in the liver. Reprod. Nutr. Dev. 36:375-389.

Grummer, R. R. 1995. Impact of changes in organic nutrient metabolism on feeding the transition dairy cow. J. Anim. Sci. 73:28202833.

Hales, C. N., and P. J. Randle. 1963. Immunoassay of insulin with insulin-antibody precipitate. Biochem. J. 88:137-146.

Hegardt, F. G. 1999. Mitochondrial 3-hydroxy-3-methylglutaryl-CoA synthase: A control enzyme in ketogenesis. Biochem. J. 338:569582

Hellemans, J., G. Mortier, A. De Paepe, F. Speleman, and J. Vandesompele. 2007. qBase relative quantification framework and software for management and automated analysis of real-time quantitative PCR data. Genome Biol. 8:R19. http://dx.doi. org/10.1186/gb-2007-8-2-r19.

Hutton, J. C., and R. M. O'Brien. 2009. Glucose-6-phosphatase catalytic subunit gene family. J. Biol. Chem. 284:29241-29245.

Ikonen, E. 2008. Cellular cholesterol trafficking and compartmentalization. Nat. Rev. Mol. Cell Biol. 9:125-138. http://dx.doi. org $/ 10.1038 / \mathrm{nrm} 2336$

Kay, J. K., C. V. C. Phyn, A. G. Rius, S. R. Morgan, T. M. Grala, and J. R. Roche. 2013. Once-daily milking during a feed deficit decreases milk production but improves energy status in early lactating grazing dairy cows. J. Dairy Sci. 96:6274-6284.

Loiselle, M. C., C. Ster, B. G. Talbot, X. Zhao, G. F. Wagner, Y. R. Boisclair, and P. Lacasse. 2009. Impact of postpartum milking frequency on the immune system and the blood metabolite concentration of dairy cows. J. Dairy Sci. 92:1900-1912. http://dx.doi. org/10.3168/jds.2008-1399.

Loor, J. J., R. E. Everts, M. Bionaz, H. M. Dann, D. E. Morin, R. Oliveira, S. L. Rodriguez-Zas, J. K. Drackley, and H. A. Lewin. 2007. Nutrition-induced ketosis alters metabolic and signaling gene networks in liver of periparturient dairy cows. Physiol. Genomics 32:105-116.

Lucy, M. C., C. K. Boyd, A. T. Koenigsfeld, and C. S. Okamura. 1998 Expression of somatotropin receptor messenger ribonucleic acid in bovine tissues. J. Dairy Sci. 81:1889-1895.

McNamara, S., J. Murphy, F. Omara, M. Rath, and J. Mee. 2008. Effect of milking frequency in early lactation on energy metabolism, milk production and reproductive performance of dairy cows. Livest. Sci. 117:70-78. http://dx.doi.org/10.1016/j.livsci.2007.11.013.

Millward, C. A., D. DeSantis, C.-W. Hsieh, J. D. Heaney, S. Pisano, Y. Olswang, L. Reshef, M. Beidelschies, M. Puchowicz, and C. M. Croniger. 2010. Phosphoenolpyruvate carboxykinase (PCK1) helps regulate the triglyceride/fatty acid cycle and development of insulin resistance in mice. J. Lipid Res. 51:1452-1463.

Morris, S. M., Jr. 2002. Regulation of enzymes of the urea cycle and arginine metabolism. Annu. Rev. Nutr. 22:87-105.

Newsholme, E., and A. Leech. 1988. Biochemistry for the Medical Sciences. John Wiley and Sons, Chichester, UK.

Nguyen, P., V. Leray, M. Diez, S. Serisier, J. Le Bloc'h, B. Siliart, and H. Dumon. 2008. Liver lipid metabolism. J. Anim. Physiol. Anim. Nutr. (Berl.) 92:272-283. http://dx.doi.org/10.1111/j.14390396.2007.00752.x.

Patton, J., D. A. Kenny, J. F. Mee, F. P. O'Mara, D. C. Wathes, M. Cook, and J. J. Murphy. 2006. Effect of milking frequency and diet on milk production, energy balance, and reproduction in dairy cows. J. Dairy Sci. 89:1478-1487.

Phyn, C. V. C., J. K. Kay, A. G. Rius, S. R. Morgan, C. S. Roach, T. M. Grala, and J. R. Roche. 2011. Effect of temporary alterations to milking frequency during the early post-partum period on milk 
production and body condition score in grazing dairy cows. Proc. N.Z. Soc. Anim Prod. 71:45-49.

Pilkis, S. J., and D. K. Granner. 1992. Molecular physiology of the regulation of hepatic gluconeogenesis and glycolysis. Annu. Rev. Physiol. 54:885-909. http://dx.doi.org/10.1146/annurev. ph.54.030192.004321.

Rémond, B., S. Aubailly, Y. Chilliard, D. Dupont, D. Pomiès, and M. Petit. 2002. Combined effects of once-daily milking and feeding level in the first three weeks of lactation on milk production and enzyme activities, and nutritional status, in Holstein cows. Anim. Res. 51:101-117.

Rémond, B., J. Coulon, M. Nicloux, and D. Levieux. 1999. Effect of temporary once-daily milking in early lactation on milk production and nutritional status of dairy cows. Ann. Zootech. 48:341352. http://dx.doi.org/10.1051/animres:19990502.

Roche, J. R., P. G. Dillon, C. R. Stockdale, L. H. Baumgard, and J. M. VanBaale. 2004. Relationships among international body condition scoring systems. J. Dairy Sci. 87:3076-3079.

Soberon, F., J. L. Lukas, M. E. Van Amburgh, A. V. Capuco, D. M. Galton, and T. R. Overton. 2010. Effects of increased milking frequency on metabolism and mammary cell proliferation in Holstein dairy cows. J. Dairy Sci. 93:565-573. http://dx.doi.org/10.3168/ jds.2009-2345.
Uchida, E., N. Katoh, and K. Takahashi. 1992. Induction of fatty liver in cows by methionine administration and concomitant decreases of serum apolipoproteins B-100 and A-I concentrations. Am. J. Vet. Res. 53:2035-2042.

Vandesompele, J., K. De Preter, F. Pattyn, B. Poppe, N. Van Roy, A. De Paepe, and F. Speleman. 2002. Accurate normalization of realtime quantitative RT-PCR data by geometric averaging of multiple internal control genes. Genome Biol. 3:research0034.0031.

Vijayakumar, A., R. Novosyadlyy, Y. Wu, S. Yakar, and D. LeRoith 2010. Biological effects of growth hormone on carbohydrate and lipid metabolism. Growth Horm. IGF Res. 20:1-7.

White, H. M., S. L. Koser, and S. S. Donkin. 2011. Characterization of bovine pyruvate carboxylase promoter 1 responsiveness to serum from control and feed-restricted cows. J. Anim. Sci. 89:17631768. http://dx.doi.org/10.2527/jas.2010-3407.

Wu, J., C. Wang, S. Li, S. Li, W. Wang, J. Li, Y. Chi, H. Yang, X. Kong, Y. Zhou, C. Dong, F. Wang, A. Xu, J. Yang, J. Gustafsson, and Y. Guan. 2013. Thyroid hormone-responsive SPOT14 homolog promotes hepatic lipogenesis, and its expression is regulated by Liver X receptor $\alpha$ through a sterol regulatory element-binding protein 1c-dependent mechanism in mice. Hepatology 58:617-628. 